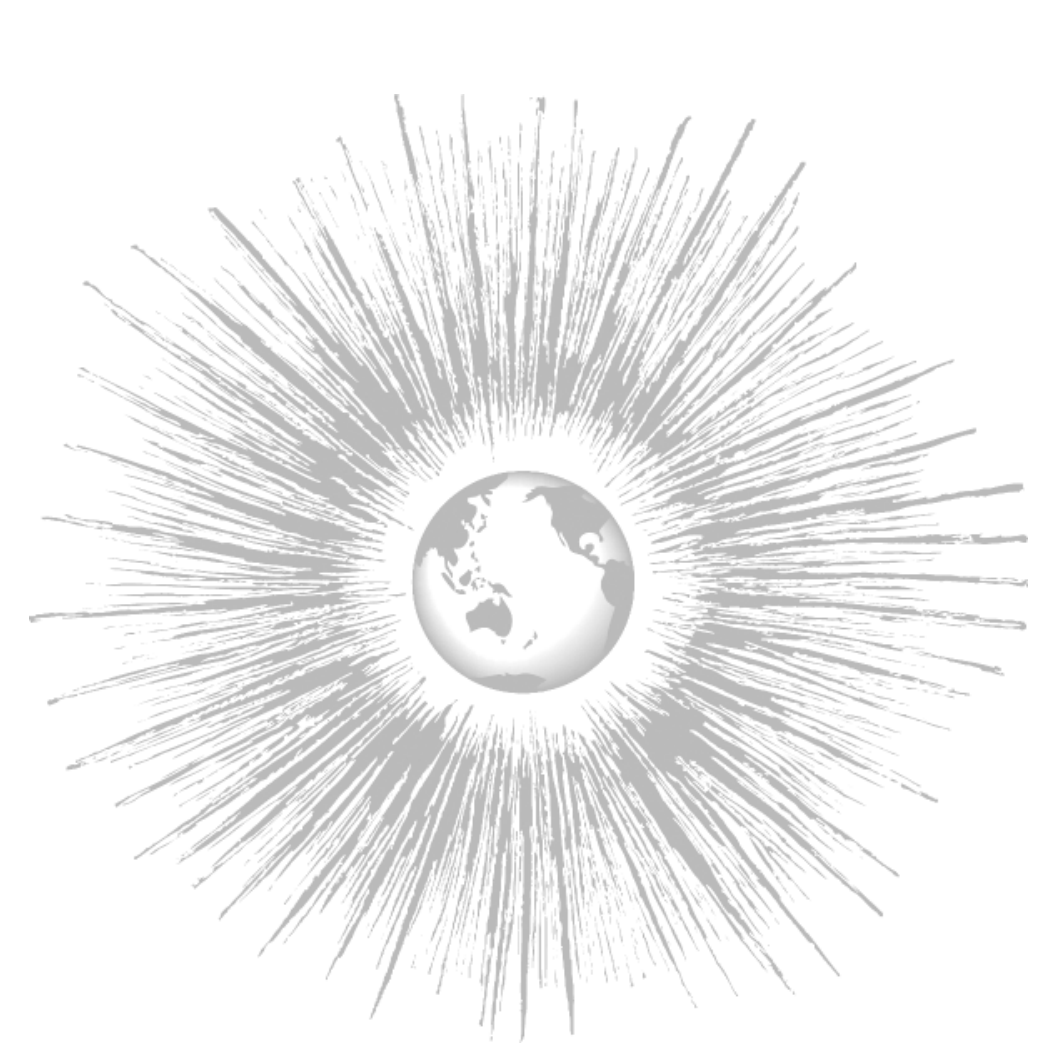

ABSTRACT:

The broadening of the world-system, which involves the geographic expansion into previously external areas and integration of new economies into its network of economic relationships, is represented in world-system scholarship by two competing views. On the one hand, Wallerstein and his associates trea incorporation as being specifically contin gent on the routine and systematic economic exchange for durable goods produced in the previously external area to the benefit of the core. In contrast, Hall and Chase-Dunn con tend that incorporation is a synchronous pro cess that takes different forms depending on

\section{Contact, Incorporation, and the North American Southeast*}

Shirley A. Hollis

\section{CONTACT, INCORPORATION, AND THE NORTH AMERICAN SOUTHEAST}

Th this study, I focus on those aspects of world-system expansion involved in its intrusion into new areas - the "broadening" of the world-economy-and the point at which we can reasonably say that the formerly external areas had been incorporated into the world-economy. Using the southeastern portion of North America as a case of world-system incorporation, this research seeks to contribute to the incorporation debate by focusing specifically on the social organization and relations that characterized the people who occupied the region prior to European contact and how contact with the world-system altered those social formations. Importantly, this research builds on the often-overlooked contribution of its initial expansion and contact with formerly external areas to the newly emerging capitalist world-system where others have tended to focus instead on the effect of colonization of the area after 1606 . I rely on previously published records of sixteenth-century European explorations of the region along with contemporary archaeological findings. The findings suggest that during the sixteenth century the area not only contributed resources to the world-economy-most often in the form of relations, not necessarily formalized, supplying

Shirley A. Hollis

Department of Sociology and Anthropology

Indiana University

Purdue University Fort Wayne

2101 Coliseum Blvd. East, CM299

Fort Wayne, IN 46805-1499

HollisS@ipfw.edu

http://users.ipfw.edu/holliss/

* I would like to express my appreciation to my colleague Larry Kuznar and the reviewers at JWSR for their helpful comments and suggestions on this article. Please direct all questions and comments to Shirley Hollis.

JOURNAL OF WORLD-SYSTEMS RESEARCH, XI, I, JULY 2005, 95-I30 http://jwsr.ucr.edu/

ISSN $1076-156 \mathrm{X}$

(c) 2005 Shirley A. Hollis 
enslaved human labor-but that it also was permanently altered by the process. These phenomena provide us with an opportunity to reassess the very nature of incorporation and to further our understanding of the reciprocal (So 1984) and synchronous (Chase-Dunn and Hall I998) nature of the process.

\section{INCORPORATION AND WORLD-SYSTEM EXPANSION}

The nature of incorporation-and in particular the point at which an area becomes "incorporated" into the world-system - has been the subject of active debate between two major factions in world-system analysis. On the one hand, Wallerstein identifies three types of areas as they relate to the worldsystem: (I) external arenas, (2) incorporated areas, and (3) peripheralized areas. Importantly, in this view, external arenas remain external so long as trade relations with previously incorporated areas are based primarily on the exchange of prestige goods or on plunder (Wallerstein 1974: 302). Incorporation is seen as having occurred only when presumably core areas establish ongoing and systematic relations with economic actors in the previously external area, the stipulation being that durable goods from the previously external area are routinely transported to the core. The incorporation of these formerly external areas is intensified as these regions become peripheral zones while, by its expropriation of surplus from the periphery (Baran 1957: 143), the core becomes more prosperous (Hopkins and Wallerstein 1982). Concurrently, internal structures are disrupted in the periphery, and its social institutions, particularly its economy, become dependent on core resources. Importantly, however, the development in the core becomes "dependent" on the exploitative exchange relations with the periphery (Chase-Dunn 1998). Although one can argue that core-peripheral relationships are mutually interdependent, disproportionate benefits accrue to the core and its economic actors (Baran 1957).

The Wallersteinian perspective has been criticized as being Eurocentric and state-centric because of its overemphasis on the effect on the world-system of capital's expansion into formerly external areas without adequate consideration of the effect on the periphery (Frank 1995b; LaLone 1999; Martin 1994). In their studies of pre-capitalist and peripheral areas, other scholars (e.g. Carlson 200I, 2002; Chase-Dunn and Hall 1997; Frank 1973; Hall 1987, 1989; LaLone 1999; Martin 1994) have extended the explanatory powers of the world-system perspective to encompass the various social formations found in the periphery, both before and after incorporation into the world-system. In fact, by recognizing the importance of understanding the social organization and social interactions present in the external area before the intrusion of capitalist forces, the current research better illuminate the impact of initial political and social
Figure 1 - Hall's "Continuum of Incorporation and Associated Factors"

\begin{tabular}{|c|c|c|c|c|}
\hline $\begin{array}{l}\text { Strength of } \\
\text { Incorporation }\end{array}$ & None & Weak & Moderate & Strong \\
\hline Market Articulation & None & Weak & Moderate & Strong \\
\hline $\begin{array}{l}\text { Impact of Core on } \\
\text { Periphery }\end{array}$ & None & Strong & Stronger & Strongest \\
\hline $\begin{array}{l}\text { Impact of Periphery } \\
\text { on Core }\end{array}$ & None & Low & Moderate & Significant \\
\hline Type of Periphery & $\begin{array}{l}\text { External } \\
\text { Arena }\end{array}$ & Contact Periphery & $\begin{array}{l}\text { Marginal periphery or } \\
\text { region of refuge }\end{array}$ & $\begin{array}{l}\text { Full-blown periphery or } \\
\text { dependent periphery }\end{array}$ \\
\hline $\begin{array}{l}\text { World System } \\
\text { Terminology* }\end{array}$ & & External Arena & Incorporation & Peripheralization \\
\hline
\end{tabular}

change that accompanies contact, not only with the world-system itself, but also on the agents of incorporation.

An expanding body of scholarship supports the assertion that incorporation is a variable process that takes different forms depending on a number of factors, including the relative location of both the previously external areas and the "incorporating" agent within the hierarchical world-economy (Hall 1987, 1989; see also Chase-Dunn and Hall 1997; Frank 1995b). Consequently, there is growing acceptance for Hall's proposition that the particular form incorporation takes in different parts of the world-from external regions to fully incorporated areas - can be situated along a hypothetical continuum representing a range of intensities in the integration of the formerly external area into the world-system (see Fig. I). Placement along the "continuum of incorporation" is dependent on $(\mathrm{I})$ the relative economic and/or military strength between the core and the area(s) being incorporated; (2) the social conditions, internal social structures, level of economic development, and type of state formation that exist in the area being incorporated; (3) the extent and nature of resistance to capitalist incorporation by people within the area being incorporated; and (4) the general level of development of the world-system itself (Shannon 1996: 129).

At the weak end of the "continuum of incorporation" and encompassing the areas identified by Wallerstein (1974) as external to the world-system are located "contact peripheries," which Hall (1986) distinguishes as having relatively little impact on the core and are themselves little influenced by the worldeconomy. At the strong end of the continuum falls what Hall refers to as "full- 
blown" or "dependent peripheries." The various forms of marginal peripheries and regions of refuge fall between the two extremes.

Because many world-system scholars overlook the process Hall refers to as contact incorporation, they fail to consider the full social impact on these areas of "political domination...by an external power [and establishment of] economic relations with the capitalist world-economy, [even while] the dominant patterns of production and reproduction within the region are still those typical of external arenas" (Arrighi 1979: 162). This study will show that even with contact-because earlier autonomous social structures, processes, and relationships are destroyed or deteriorate and cease to be dominant within the region-significant social changes may occur (Hall 1989). In the place of the old patterns of social organization new ones that are conditioned by core capitalism are imposed.

First, increased influence flows largely from the core to the periphery; in fact, some scholars argue that these less intensive types of incorporations, which often take the form of exploration or pre-emptive colonization, are necessary prerequisites to the later transition to capitalism that takes place in full incorporation (Hall 1989; Osgood 1904). However, there is less agreement regarding the benefits gained from the relationship by the formerly external area. Importantly, the core is made more prosperous by the expropriation of surplus from the periphery (Baran 1957: 143). Concurrently, the periphery enters into a state of dependency on core relations and resources because its own internal structures have been disrupted (Bradby 1980).

Second, Wallerstein (1988: 20I) contends that incorporation into the worldsystem "involve[s] sometimes the remolding of existing political structures, sometimes their dismemberment, sometimes the fusion of several, and sometimes the creation of entirely new and quite arbitrary delimited structures." The transformation of formerly autonomous political structures is an important aspect of incorporation since the "alliance between political and economic factors...necessary to break down processes of [social] reproduction.... are effected through a mixture of the political and the economic" (Bradby 1980: 104). It can be argued that this overlooks the impact of contact on social relations within that area, which I contend are equally important to any understanding of incorporation. This is the case since intra- and inter-class relations, institutional arrangements, and relations both internal to the newly incorporated area and external with agents of capitalism in the core zones of the world-economy set the context within which subsequent local changes occur (Hopkins and Wallerstein 1987). It must be noted, however, it is a process that Wallerstein sees as occurring with full incorporation but not with less intense forms of incorporation.
Third, because the influence of incorporation is cumulative, as a region becomes more tightly incorporated into the world-economy, "external pressures impinge more forcefully on local groups. When such pressures are sufficiently strong and of sufficient duration, the structure of local groups will be changed" (Hall 1989: 20-22). Importantly these structural changes tend to be less reversible even in the unlikely case of the incorporation project being abandoned (Wolf 1982: 311). It is also more likely that core development-and particularly core production processes-will become increasingly dependent on the continued availability of cheap resources from the new periphery. The stronger the incorporation, the more likely it is that local structures in the previously external area will be affected and the less likely it is that those in the newly incorporated area will be able to successfully resist the encroachment of external forces of social change. However, even though it may fail over the long haul, resistance may create political barriers or financial losses that impede the process (Dunaway 1996).

The first steps in North America's incorporation into the European worldsystem, while often framed as the "discovery of the New World," imposed significant changes on the social organization of the native populations in the region that have received far less attention than the significant and well documented benefits that accrued to Western Europe. For instance, Frank (1978b: 63) asserts that "the precious metals from the New World enabled Western European countries to settle directly or indirectly the deficit in the trade balance with the Orient" that had limited European merchants' ability to expand their trade. Furthermore, according to Marx and Engels (1962: 3-4),

The discovery [sic] of America, the rounding of the Cape, opened up fresh ground for the rising bourgeoisie. The East-Indian and Chinese markets, the colonization of America, trade with the colonies, the increase in the means of exchange and commodities generally, gave to commerce, to navigation, to industry, an impulse never before known.

In what follows, I examine patterns of social organization and relationships that characterized much of the southeastern region of North America prior to European contact and incorporation. I focus specifically on the economic, political and social structures that had been established by the Mississippians and how they were affected by European contact, the goal being to understand more completely the effects of incorporation into the European world-system on pre-capitalist societies. Additionally, it is also my goal to examine the bidirectional nature of incorporation. 


\section{THE MISSISSIPPIAN SYSTEM}

The Mississippian System ${ }^{1}$ is widely recognized as having emerged between 750 and I000 C.E. and to have flourished over the next five to seven centuries (Smith 1990). Comprising a network of relatively autonomous social groups or cultures, in the centuries immediately before and concurrent with European contact, the "core" of the Mississippian System was centered in the American Bottom near present-day Cahokia, Illinois. It encompassed most of the southeastern region of North America and occupied much of the region encompassing the Mississippi, Ohio, and Tennessee river valleys. Integrated into a complex economic, political, and social system, the Mississippians engaged in common exchange involving essential food-stuff, information, prestige-goods (Earle 1987; Peregrine 1992), and complex political and military alliances (De Pratter 1983; Hally 1993; Peregrine 1992; 1996a; Smith 1978; Smith and Hally 1992; Wolf I982).

There is a general consensus among scholars that the Mississippian system, particularly its core region, had begun to disintegrate sometime between 1300 and 1500 C.E. possibly from sustained warfare (Wolf I982), unsustainable population growth (Chase-Dunn and Hall 1998), relocation of population because of excessive demands by Cahokian elites (Pauketat and Emerson 1997), demographic changes caused by over-dependence on corn and the depletion of the soil (Galloway 1995), increased self-sufficiency in the peripheral areas, or the normal cycling between complex and simple chiefdoms that Anderson (1994:8) argues happens when systems fail to "evolve more efficient higher-level regulatory or control units." However, there is considerable support for Lewis's assertion that the centuries between $\mathrm{I} 300$ and I700 C.E. "marked the greatest social complexity of Mississippian groups" in the region surrounding the confluence of the Mississippi, Ohio, and Tennessee rivers (Lewis 2000: 290) and was apparent to European explorers upon their travels through the deep South in the sixteenth century. For instance, Spanish historian Pietro Martiere d'Anghiera, who traveled through the southern Appalachian area in I52I with the de Ayllon caravel, described a single "ranked, hierarchical society with settlements over large areas owing allegiance and tribute to specific communities and leaders" (cited in Anderson 1994: 56-57). Members of the DeSoto expedition similarly noted in the 1530 s the presence throughout the region of a distinct pattern of ceremonial

1. The representation of the Mississippian system presented in this research is an "ideal type" based on an extensive review of the scholarly literature, primarily from the discipline of Archaeology.

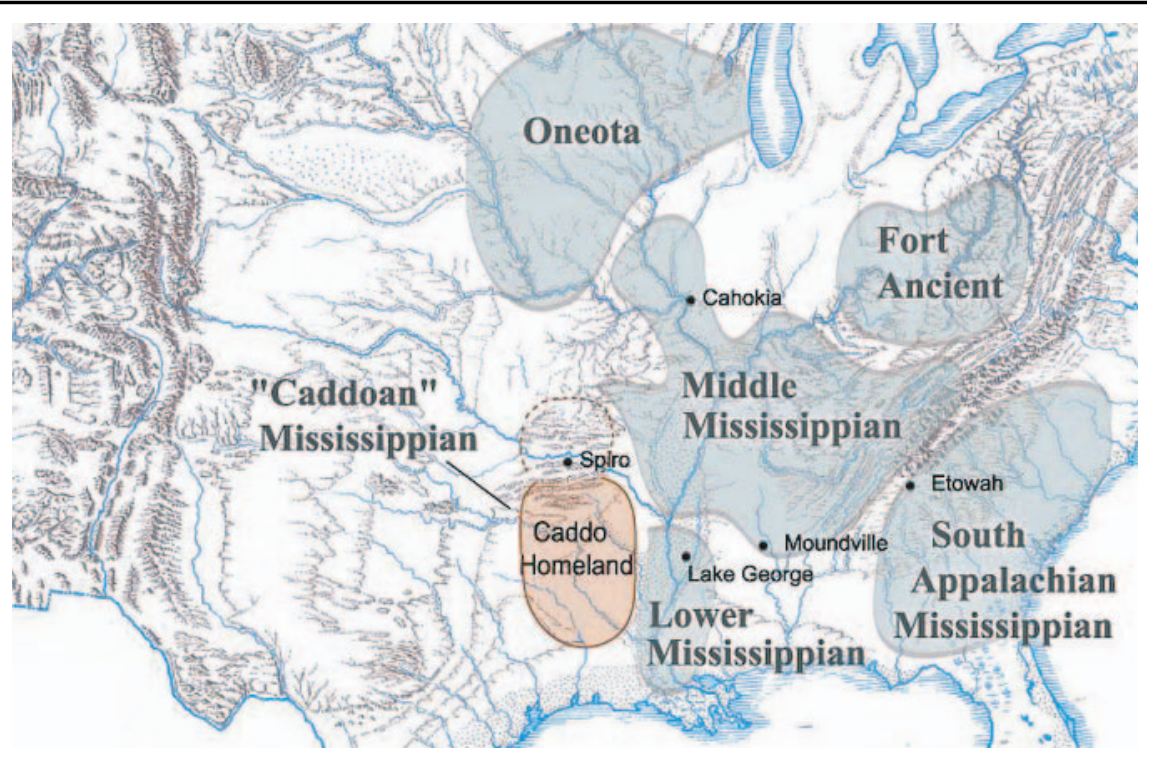

Source: Base map by Erwin Raisz, from the "Texas Beyond History" website

http://www.texasbeyondhistory.net/tejas/fundamentals/miss.html. Used by permission of Raisz Landform Maps.

temples and burial sites that were likely cultural remnants of earlier interconnected and ranked social groups or societies (Curren 1984; Curren, Little, and Lankford 1982). Furthermore, Hudson (1990) provides evidence that the system continued to flourish along the eastern lowlands as late as 1566 when the Juan Pardo expeditions passed through the area.

What Peregrine calls the Mississippian System was characterized by, among other things, construction of ceremonial mounds and the organized production of maize, beans, and squash (Jeske 1999; Muller 1997; Swanton 1946; Wolf 1982). This transformation allowed the emergence of a horticultural economy based largely on an increase in population, the organized production of corn, the emergence of a surplus, and an elaborate trade network. Additionally, the system was notably hierarchical (Jeske 1999) with a complex network of powerful leaders who became linked together into a "pan-Mississippian web of competition for access to prestige-goods" (Peregrine 1999: I). The southeastern groups were characterized by intraregional complex chiefdoms co-resident alongside less centrally organized social groups-“core-periphery differentiation without much evidence of core-periphery domination" (Kowalewski 1996: 29). For instance, de Soto's journal describes "an elaborate social organization 
where chiefs lived in sacred buildings, manipulated social networks covering large territories and held the power of life or death over their subjects" (cited in De Pratter 1983).

Although Hudson (1990: 53) argues that the Mississippian system was not so much a "culture" as a fundamental economic and social system that was transformed from the earlier Woodland tradition and was "marked by a pervasive and progressive sameness among Indians over a large area of the Southeast," there is considerable evidence that a number of cultural variations made in the Mississippian System (see Fig. 2) originally emanating from the 'core' or center had first been developed at Cahokia (O'Brien 1992). The primary focus of the current research is on the Middle and South Appalachian Mississippians.

The Middle Mississippian core region has been described as a 'true Mississippian Culture' of rulers, craft specialists, merchants, warriors, and other elites who from the central towns exercised control over the residents of surrounding farmsteads and villages (Porter 1974: 30-3I). The culture was distinguished by "a more intensive and formal network of inter-regional trade, and perhaps a greater degree of political centralization (and perhaps ascribed positions of authority) than other Mississippian variants" (Peregrine I996a: xxi; see also Hudson 1990). It was also distinguished by the goods produced-unique pots and ceramic vessels, feathered ceremonial cloaks, and the like, created by craft specialists hired by the chief. This helped him maintain authority and legitimacy and to help seal the patron-client relationship that appears to have been the primary stabilizing factor in their world (Pauketat 1994; see also Peregrine 1996b: IO). By IIOO C.E. the Middle Mississippian culture had encompassed the central Mississippi River valley, and the lower Ohio and Tennessee river valleys (Peregrine 1996b); and it had spread eastward across the Appalachian mountain chain and included middle and eastern Tennessee, northern Mississippi and Alabama and the northwestern corner of Georgia. The system included the paramount chiefdom located at the large population center at Cahokia (Hall 1991; Kelley 1991; Muller 1997; Peregrine 1996a) and the complex chiefdom at Moundville, in what is now central Alabama (Hudson 1976; Peebles 1983; Peregrine 1996b). ${ }^{2}$

The South Appalachian Mississippian culture groups were dispersed across the area south and east of the Appalachians. The population included organized and interrelated social groups in south Alabama, north Florida,

2. There is disagreement as to whether it also encompassed Etowah and Coosa, in northwestern Georgia (Hally, Smith, and Langford I990).
Georgia, and the Carolinas. The variant of culture in this area differed in a number of ways from the Middle Mississippian groups. In particular, the South Appalachian groups were characterized by a less centralized political organization and their political and social leaders attained their positions because of their achievements rather than by way of a system of ascribed social and political ranking (Peregrine 1996b). Hudson (1976: 91) suggests that the South Appalachian groups may have in fact been part of "a local Woodland culture which was modified by borrowing from the Mississippian culture to the west." This has lead Hudson to further propose that these migrants may well have become more centralized and joined the Mississippian system as a defense against encroaching populations, who possibly had migrated outward from the Cahokian center while it was still dominant until its collapse began around 1300 C.E. (Jeske 1999; see also Swanton 1946: I4).

\section{INDIGENOUS STRUCTURES AND MEDIATED SOCIAL CHANGE}

The manner in which the Mississippian System was first incorporated into the world-economy established in the formerly external territory a variety of new capitalistic social, economic, and political structures, which arguably conditioned the development of the region for centuries to come (Hollis 2000). Basing my analysis on an extensive critical examination of published historical and archaeological research, I explore these unique political and economic structures that were in place prior to contact and how they may have influenced and were influenced by the incorporation of the region and its people into the world-system.

\section{Political Structures}

The Mississippian system was organized around a hierarchical network of chiefdoms, some simple, others complex, with a few paramount chiefdoms (see Fig. 3), and progression from one level to another was distinguished by the increasing number of levels involved in the group's decision-making processes (Anderson 1994; Pauketat 1994). ${ }^{3}$ Simple Mississippian chiefdoms exercised authority and administrative control over a relatively small area that was com-

3. A chiefdom is "a society with a definite structure, and with some systematic form of political organization... [including] a definite mechanism for replacing the political leader" (Hall I989: 29-30). Service (I97I: I 34, I44-I45) describes chiefdoms as "redistributional societies with a permanent central agency of coordination... [with] pervasive inequality of persons and groups." 
Figure 3 - Organization of Chiefdoms and Hierarchy of Control

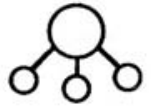

Simple Chiefdom

One decision-making leve

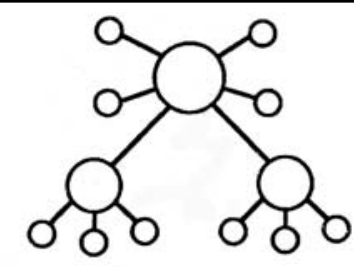

Complex Chiefdom

Two decision-making levels

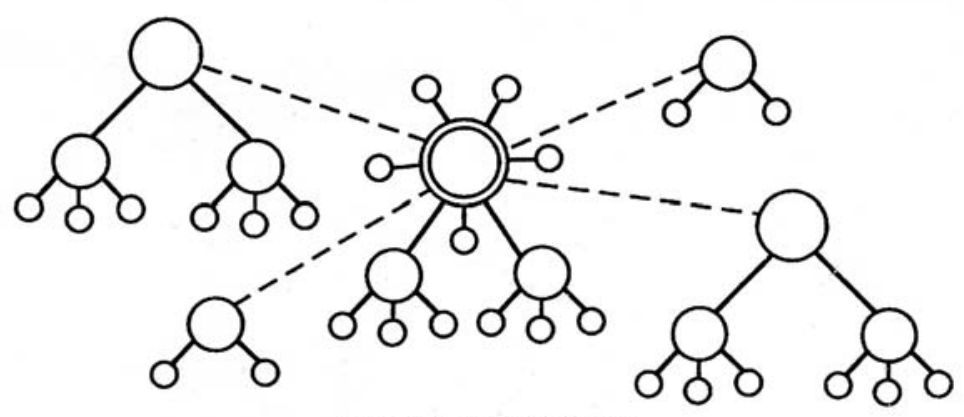

Paramount Chiefdom

Two or three decision-making levels

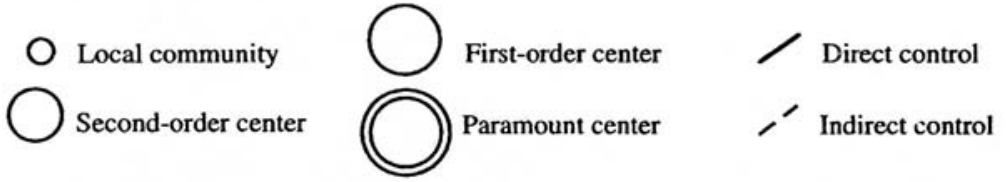

Source: Anderson, David G. 1996. "Fluctuations between Simple and Complex Chiefdoms: Cycling in the Late Prehistoric Southeast." Pp. 233-252 in Political Structure and Change in the Prehistoric Southeastern United States, edited by John F. Scarry. Gainesville: University Press of Florida, p. 233. Used by permission of the publisher.

prised of perhaps a small village or some number of farmsteads surrounded by uninhabited buffer zones (Scarry 1996a). These social formations differed in a number of ways from complex chiefdoms, which emerged when a powerful chief's sphere of authority expanded sufficiently so that he or she came to exercise direct or indirect control over one or more other simple chiefdoms.

Paramount chiefs enjoyed power sometimes over several complex chiefdoms and possibly some number of simple chiefdoms at the same time (Smith and Hally 1992). The leaders of these chiefdoms enjoyed control that was "one or two administrative levels above the local community" (Anderson I991: 232). Furthermore, the relations between simple, complex, and paramount chiefdoms
Contact, Incorporation, and the North American Southeast

were decidedly hierarchical in nature and involved the payment of tribute (e.g. corn, preferred selections of deer meat, etc.) by the local community to those above it in the hierarchy (Kelly 1997; Knight 1990; Welch 1986) and the distribution of exotic status markers to secondary mound sites in order to secure regional status positions (Peebles I983).

The mound sites that adjoined the population centers appear to have been largely ceremonial, administrative, or religious in nature. However, Johnson (1994: I14) contends that "the common folk may have gotten more than religious advice and alliances from the elites, for there is some evidence..+that corn was stockpiled at the major centers presumably to carry the general populace through years of bad crops." Barker (1992: 68) argues that such hoarding was more than likely used to foster a system for the legitimacy of elites and solidarity between them and the commoners. There is also support for the idea that it may have lessened intertribal conflict during lean times. In fact, Milner, Anderson, and Smith (199I) argue that the system mediated local conflict in a number of ways. In parts of the system-and this appears to have been particularly true in the South Appalachian area-complex chiefdoms may have emerged as a way of combining defensive forces against common enemies, perhaps other but stronger Mississippians (Larson 1980).

Whereas a purely kin-based system would have been characterized by status differences related to kinship, the Mississippian system differed in that the hierarchical class structure and status groups were almost certainly important in structuring local relations of social control (Mehrer and Collins 1995). Consequently, it has been argued that the Mississippians could reasonably be identified as the beginning of a class system that might, if left uninterrupted, have led to the development of a state mechanism (Carneiro 198I; Pauketat 1994). In the Mississippian culture, paramount chiefs also exercised ceremonial, political, economic, and administrative control over villages that were often separated by great distances (Hudson 1990). As an example, the Coosas of Georgia dominated and exacted tribute from less-powerful bands throughout eastern Tennessee, northeastern Alabama, and northern Georgia. The Lady of Cofitachequi in what is now South Carolina exercised authority over a dozen or more lesser chiefdoms located from the coast far into the Blue Ridge mountains (Hudson 1976). The archaeological evidence suggests that these relationships were cemented with trade and social relations between remote local chiefdoms and powerful paramount chiefdoms which involved payment of tribute, 'downthe-line' exchange, and powerful ideology necessary to subordinate and secure the allegiance of lesser and often distant chiefs (Pauketat 1994; Pauketat and Emerson 1997). This also may well have been the case with mortuary rituals and other burial practices performed throughout the system and associated 
with the ceremonial mounds for which Mississippian settlements are noted (Nassaney 1989).

There is a good deal of evidence that elites controlled the production of unique and elaborate trade goods, such as clay pots, shell-tempered pottery, decorated vessels, flint blades, axes, and beads made from sea shells that had been collected more than a thousand miles away. Additionally, they controlled exchange relations, information, and political alliances. For instance, they incorporated external groups into their sphere of influence, possibly by accommodating groups seeking to strengthen their own positions or perhaps by imposing those relationships on them.

Hierarchical classes and status groups were central to the expansion of the system and, typically, are important to the incorporation into its network of political, economic, and social relations of remote "external" regions. This is particularly important because expansion was so critical to meeting the need to increase productive capacity (Smith 1978). Kowalewski (1996: 30) contends that the "link between interregional diplomatic-military activity, basic production, and regional and local settlement patterns [is an] obvious way for largescale interactions to structure behavior at the local and household levels." The resettlement of Mississippian population groups into more remote areas was clearly one way productive capacity could have been increased and appropriated by core powers. Importantly, the folklore of a number of southeastern indigenous groups would appear to support the notion that the composition of many of the southeastern culture groups had been the result of migrations into the area. For instance, Cotterill (1954) contends that the historic group known as the Catawbas, who claimed as their territory much of what is now South Carolina, believed that they had migrated from the neighborhood of the Great Lakes in some remote past. Likewise, the Cherokee share a similar story of their origins that places their ancestral roots in the same general area (Mooney 1982; Perdue 1989). It is reasonable to attribute such relocations to depopulation that resulted from the transoceanic diffusion of diseases (Crosby 1986; see also Hoig 1998 and Hudson 1976), the ravages of assault and warfare, (Hudson 1976), and the capture, enslavement, and export of large portions of the population (Nash 1992).

\section{Economic Structures}

The more complex Mississippian social groups were generally located in rich river basins in the interior and produced goods not only to meet the consumption needs of the local people but also as objects of intraregional trade; in return, they received from great distances trade goods that were differentially distributed, with elites controlling other members' access to them (Peregrine 1992). Although Johnson (1994) contends that the trade lacked spatial and chronological continuity and was not an important factor in the Mississippian's development, evidence suggests that the natives of the Southeast engaged in long-distance trade as early as around 3600 B.C.E. (Muller 1997). Certainly well before the emergence of the Mississippian system, "an extensive trade network appears to have developed during the Woodland period" and even in archaic Poverty Point (Hudson 1976). This network involved inhabitants engaging in regularized exchange of locally produced goods, which held some prestige value elsewhere, for goods they were lacking or that were scarce. For instance, freshwater pearls appear in archaeological sites far from the coastal areas of what is now South Carolina where they are indigenous. Copper from the Great Lakes area has been found in Mississippi, and copper and mica from the Appalachian area and marine shells from the panhandle of what is now northern Florida have been found throughout the system in the ruins of ancient villages (Hudson 1990).

Trade was not simply internal to the Mississippian system. For instance, regular trade between villages in the Appalachians and the Iroquois in the northeast was evident along the ancient Great Warrior Path that connected the areas, and even more distant trade is suggested by South and Central American artifacts unearthed among Mississippian ruins (Keel et al. 1996). However, there is evidence that trade networks expanded after the emergence of the Mississippian system and became directly integrated into new patterns of exchange and distribution that operated under a new set of rules as regards power and prestige. The control of trade relations and the distribution of prestige goods to peripheral areas within the Mississippian system accounted in part for the power exercised by paramount and complex chiefdoms, which, in turn, was associated with greater stability and security than was evident in areas external to the system where intertribal warfare was more frequently a way of life (Peregrine 1992; Scarry 1996b).

In spite of similarities between the various Mississippian cultures-which can in part be accounted for by the dispersal of people and regularized communication and trade-natives of the Southeast were a "diverse peoples whose social, political, and economic relations with each other were complex" (Trigger and Swagerty 1996: 327). Indigenous social systems ranged from the simple groups engaged in more nomadic activities (Hudson 1990) that were mainly located in the piedmont and along the coastal regions to relatively more advanced horticultural societies that were consistently involved in the production of maize, beans, squash and other agricultural staples, were technologically superior and 
most often organized into complex chiefdoms. ${ }^{4}$ While many of the natives of the Southeast lived as village dwellers with extensive hunting territories, few of the Mississippians were nomadic (Trigger and Swagerty 1996). This is at least partially related to the mode of production adopted under the new cultural and economic system - that is, the organized production of corn and other food products and extensive trade in prestige goods-and partially related to the organization of the population into relatively permanent centers, often with elaborate defensive structures and political alliances. The argument is made here that the less organized, more mobile people that later settlers encountered might better be explained by the violent convergence of unequal world-systems that led to the destabilization of previously cohesive groups, as proposed by Wolf (1982), Peregrine (1992; 1996a), and Kowalewski (1996).

\section{THE MISSISSIPPIANS AND EUROPEAN CONTACT}

From 1500 onward, Spanish explorers and conquistadors, along with their enslaved Africans and natives, made contact with people who lived along the coast of Florida (Anderson 1994) and farther inland. For instance, in 1513, Ponce de Léon encountered indigenous people who clearly had prior experiences with European contact (Swanton 1946), indicating almost certainly that de Léon was neither alone nor first in his quest for slaves and other sources of wealth. Throughout the sixteenth century, while Europeans were exporting tons of gold and silver and thousands of enslaved natives from the Americas, they were also introducing onto what had been 'virgin soil' contagious diseases from which the indigenous people had no natural resistance (Crosby 1972, 1976). What ensued has been described as highly lethal "germ warfare" (Trigger and Swaggerty 1996) that weakened the ability of the native populations to ward off the advance of 'civilization' and to withstand the forced labor to which they found themselves subject (Jennings 1975). Evidence, however, tells us that the native people did not succumb to their conquerors willingly, but rather exerted substantial resistance. However, the warfare that ensued, in the face of the Europeans' superior technology of war, further weakened them.

4. Prestige or luxury goods are part of such a complex of social relations because they are often vital in the social reproduction of political relations and power structures (Abu-Lughod 1989; Schneider 199I). Chase-Dunn and Hall (1997: 14) also assert that "all regularized material exchanges should be included as criteria for system boundedness. Thus, it is necessary to consider how relatively localized networks of bulk-goods exchange are nested within much larger networks of prestige-goods exchange in any system."
It is worth noting here that Europeans' experiences in North America were to be quite different than in other parts of the Americas, in large part because the indigenous people lacked the strong centralized state mechanisms that had been found in South and Central America and which served as the principal instrument by which the Spaniards would "dominate and colonialize them... [and] organize the division of labor that would put the indigenous population at their service" (Frank 1978b: 43). Because the North American people and their labor were more loosely organized and less centrally controlled by their paramount chiefdoms, Europeans were hindered from establishing the coercive labor controls and mechanisms of domination they would have needed to more effectively exploit the population. As a result, relations between the indigenous groups and the Europeans were more conflictual in nature. Nonetheless, thousands of natives were kidnapped and enslaved by the Europeans and placed into coercive labor systems elsewhere, mostly in the West Indies and Brazil (Curtin 1990), and, in the process, the indigenous peoples' capacity to physically and socially reproduce themselves was greatly diminished.

\section{Contact and Conquest}

Archaeological evidence establishes that when the Norse arrived in the area of Newfoundland and Labrador on the North American continent around Iooo C.E. (McGovern 1980) they soon departed, leaving few traces behind them with no indication of long-term damage to the populations with whom they surely came in contact. However, the journals left by Colón and his commentator Las Casas document a bloody conquest that resulted in the enslavement and death of thousands of native people (Smith [1776]1937; Sauer 1966; Frank 1978a). Confident in the superiority of European skills of war and technology, Colón took a stance toward the indigenous populations that foreshadowed what would become the dominant pattern followed by Europeans in dealing with the North American natives. Although he boasted that "with fifty men we could subjugate them all and make them do whatever we want" (cited in Zinn 1980: I), he used considerably more men to succumb the native people and enact his plan. He, along with other Europeans, succeeded in destroying most of the native populations from the Caribbean islands alone between 1492 and the I520s. Their demise came at the hands of soldiers who tortured, mutilated, murdered, enslaved, waged war, and imposed upon them inhuman labor conditions and exposed them to a variety of contagious diseases. In fact, Sauer (1966) estimates that the population of Santo Domingo alone declined from about a million inhabitants to "insignificant numbers" during the period of Colón's occupation. This first recorded contact in many ways established a 
colonial model that applied to European contact with most native American populations.

There is no record to suggest that when Colón landed in the Bahamas in I 493 he or his men traveled on to the North American mainland. History next tells of Giovanni Caboto (John Cabot) and his crew of eighteen sailors landing in 1497 somewhere between Maine and Labrador, claiming the "new founde lande" for the British crown, and establishing the basis for England's claim to North America (Croxton 1990). Although there is no known account of Caboto and his men having had direct contact with indigenous people, European goods located at archaeological sites far removed from that area have led Trigger and Swaggerty (1996) to speculate that they could well have been artifacts from the Caboto voyage, and, at the same time, can be taken as an indicator of the natives' involvement in a complex pattern of long-distance trade. This suggests, too, that, when we consider the migratory range of the various bands of native North Americans, it is at least possible that native groups in the distant interior soon felt the effects of the European pathogens the explorers almost surely carried and would have passed on to anyone with whom they came into contact. In fact, I suggest, the diffusion of European diseases through the contacts may well account for the accelerated depopulation of the Mississippian culture that, in some parts, had begun to collapse around 150 years earlier.

When Hernán de Soto traveled though the Southeast between 1539 and 1543, there were already indications of extensive depopulation in certain areas, indicating that they had also come into direct or indirect contact with European pathogens, in this case left, along with Spanish weaponry and other goods, by the expedition of Lucas Vásquez de Ayllón as it attempted colonization in 1526, or perhaps Giovanni da Varrazzano's men. While da Varrazzano's explorations were concentrated along the eastern coastline in 1524, De Ayllón led some 500 colonists up a river he named the Río de Guadalupe, to a site on what is now called Parris Island, South Carolina, and perhaps beyond. Of equal importance to this discussion, de Ayllón also captured and enslaved natives and exported them to the West Indies, where they presumably were sold into the sugar industry (Nash 1964). This suggests that, although these early colonization attempts were unsuccessful, they were aimed, not simply at exploration and plunder, as had been the primary goal of the Europeans, but also at establishing permanent settlements and the capture and export of slaves.

5. Peregrine (1996a) argues that this cultural pattern was a defining characteristic of the Mississippian system.
In spite of their failures and our difficulty in assessing the full impact of their early contacts, we know that virtually the entire Savannah River valley had been depopulated or abandoned by 1540 when de Soto arrived in the area (Hudson 1976). And although there is no way to know for certain whether the depopulation was associated with European diseases or warfare with Ayllón's men, or both, the location of artifacts from that expedition having been found some distance inland from the original landfall indicates that the events were related (Hudson 1990; Hoig 1998). Importantly, it is entirely possible that the natives' experiences with Europeans produced the open hostility that subsequent explorers encountered (Brown 1966; Hoig 1998). These encounters could have also been associated with the hostility already noted between various native groups.

Our understanding of the role of the European states in these early encounters and efforts at colonization is important to the current discussion because it was through these early explorations that European powers institutionalized in North America a particular form of state-sponsored domination. For instance, although private adventurers were instrumental in carrying out Europe's colonialization policies, they did so under the auspices of the various state powers (Beers 1908), but with the anticipation of great personal profit and the private acquisition of large tracts of income-producing land. European royals extended to various "explorers" monopoly rights to conquer and plunder previously unsettled' regions in exchange for a share of the profits and subsequent sovereignty over newly settled areas. The charter served as the mechanism that legitimated the colonial project in large part because charter holders were designated as representatives of the King, and the King of God. This can be seen in the charter granted to de Soto by the Spanish crown, which included the following terms:

$[Y]$ ou will take...five hundred men with the necessary arms, horses, munitions, and military stores; and...make the said conquest and settlement within a year first following, ,.. you will take the necessary subsistence for all that people during eighteen months - rather over than under that timeentirely at your own cost and charges.... I bestow on you the conquest of these lands and provinces.

I give you...power and authority...to conquer, pacify, and populate the lands.... [Y] ou shall choose... have the two hundred leagues...with the annual salary of fifteen thousand ducats, and five hundred ducats gratuity.... [T] of the gold which may be taken from the mines shall be paid us the tenth,...; but from the gold and other things that may be got by barter, or is spoil got by incursions, or in any other manner, shall be paid us thereupon one-fifth of all.... [A]ll other, of the character that may be and is found, whether by finding it by accident or discovering it by search, shall pay us the half... and 
shall any person or persons have gold, silver, stones, or pearls, taken or found, as well in the said graves,... or Indian temples... or other concealed religious places, or interred... and do not make it known...they have forfeited all the gold and silver, stones and pearls, besides the half of their good to our tribunal and exchequer. (Cited in Hudson I990)

The king endowed de Soto with the authority to conquer sovereign peoples, plunder their temples and gravesites, capture them and sell them as slaves, steal and destroy their property, and establish over them feudal-like domains. And de Soto and his men appear to have carried out their mission with enthusiasm and determination.

Important to the relative success of his missions, de Soto was an experienced conquistador when he arrived on the North American continent, having joined at the age of eighteen Pedro Arias Dávila's expedition to the West Indies. By 1530, after exploring the Florida coast with Ponce de León, he had amassed considerable wealth by developing a lucrative slave trade in Central America. Joining Francisco Pizarro in his plundering of Peru in 1532, de Soto had been a critical force in the Spanish defeat of the Incas (Bourne 1922). Endowed with immense wealth but jealous of Pizarro's success, de Soto returned to Spain in search of a governorship of his own in the Americas. He was subsequently appointed governor of $\mathrm{Cuba}$ and commissioned by the crown to conquer what is now Florida (Milanich and Hudson 1993).

Superior technologies of war, horses, and attack hounds gave de Soto and his men a decided advantage over the natives, who when they tried to avoid contact or subjugation were simply tracked down and killed or enslaved. And because De Soto was experienced at conquering and enslaving Indians and Africans and operating in a hostile environment where Europeans were in a distinct minority, he was also experienced at operating with impunity as he used brutal and coercive measures to establish and maintain social control. Furthermore, he could justify these acts to himself and those around him by advancing the blend of colonial ideology and Christian rhetoric of the day as described by Adam Smith ([1776]1937: 528-29):

The pious purpose of converting [the natives] to Christianity sanctified the injustice of the project. But the hope of finding gold there was the sole motive which prompted them to overtake it.... All the other enterprises of the Spaniards in the world subsequent to those of Columbus seem to have been prompted by the same motive. It was the thirst for gold.

Evidence that the de Soto expedition caused even more extensive demographic changes and social transformations than earlier explorations is revealed by contrasting the accounts of his expedition with those left by subsequent explorers (see e.g. Hudson 1990). The effect of his entourage on the native populations was especially destructive, in part because their extensive travels throughout the Southeast brought them into direct contact with more of the native populations than did the shorter pathways taken by earlier explorers. There are, however, also indications that the tactics used by de Soto in dealing with the local populations were more savage than those used by others, with the possible exception of Colón. Examples of the abusive nature of de Soto's relations with the natives are found in his own journal as he recorded accounts of his entourage journeying through the South, beginning with his first landing on the Florida coast (Milanich and Hudson 1993). For example, las Casas recorded that soon after their landing on the coast of the Florida peninsula in I539:

Captain Juan Ruiz Lobillo went out with about forty or fifty infantry, and they captured several Indian women.... On another occasion, de Soto sent Juan de Añasco with some infantry in the ship's boats along the shore... Añasco killed nine or ten Indians.... De Soto sent Vaso Porcallo with forty cavalry and some infantry, but when they got to where Añasco was the Indians had already fled. When they failed to find Indians on the island, the Spaniards spread out and conducted raids, capturing some women. (Cited in Milanich and Hudson 1993)

Although the records of these few days are typical of the entire expedition, they also give evidence that at almost every major settlement, the services of scores of men were exacted to carry supplies and contraband. Additionally, as many as a hundred women were demanded at the same time for unspecified purposes (Hudson 1976).

While some captives were able to escape from de Soto en route, hundreds more perished from disease, heat, and overwork; others were killed for disobeying or misunderstanding instructions. As the de Soto expedition traveled northward from southern Florida they kidnapped and enslaved natives at virtually every stop. The provisions transported from Cuba were limited, fell far short of meeting the terms of the royal charter, and required the expedition to locate food wherever they went. Consequently, de Soto and his men frequently destroyed entire crops and storage facilities of entire villages as they stole food supplies presumably necessary to supply the dietary needs of the large entourage. ${ }^{6}$ This would have been important not only in depriving these native groups of supplies required to meet their own dietary needs, but also in the mainte-

6. The acceptance by other European nations of this claim by England was based on the rule that the nation who succeeded in first landfall had the strongest claim to dominion and is evidence of the informal rules of colonization that earlier represented the interstate system (Beer 1908). 
nance of hierarchical relations within the extended social group. This is indicated by the fact that, although every village had corn and other foodstuff on hand, the villages of complex and paramount chiefdoms throughout the region held especially large stores of corn that were apparently distributed to villages during droughts and other crop failures.

Although the noted stores of food were particularly attractive to the Spanish whose daily needs were great, the natives did not always freely relinquish their much-needed supplies. Consequently, de Soto and his men frequently destroyed crops and robbed corncribs along the way and left the villages ill prepared to meet the approaching winter. ${ }^{7}$ Consequently, De Soto records that, as word spread in advance of his expedition, entire villages were abandoned and residents scattered throughout the countryside to avoid being kidnapped and ravaged. The abandonment of their villages, however, did not stop de Soto and his men from destroying not only their crops but also their burial places. The materials the natives had used in building their sacred temples were taken to construct temporary quarters for themselves, after these holy places were first pillaged and ransacked (Milanich and Hudson 1993: 63). The long-term effects of such destruction are not recorded, but they almost certainly led to reduced prestige and legitimacy for local leaders and the lessening of the ideological power associated with their sacred places.

Disparity in the technologies of war between the Europeans and natives played a major role in de Soto's conquest and decimation of the native populations. Ships, weapons, armor, and other material advances gave the European conqueror a decided advantage in warfare. However, Hudson (1976: I13) concludes, "it was the horses that won the battle for the Spaniards. The Indians were superior to Spanish foot soldiers, but they were no match against the cavalry." This was demonstrated at the battle of Mabilia, which Hudson (1990) describes as an ambush of de Soto and his men by natives who had banded together in an apparent effort to better defend themselves from the expedition and its destructive effects.

The de Soto expedition made its way through Florida, into what is now North Carolina, westward into eastern Tennessee, southward into northern Georgia, and across Alabama to Mississippi before turning northward again into western Tennessee. After de Soto's death, his men continued westward into Texas before returning to the Gulf Coast. This circuitous route exposed thousands of the indigenous people directly to the Europeans, their culture and

7. Hudson (1990: 24) asserts that "sixteenth-century expeditions, being unable to carry along a sufficient supply of food, had to obtain it, by persuasion or force, from the people they encountered." diseases. Within a few years the effects had diffused to the remainder of the region's population. In the decades following de Soto's expedition, numerous Spanish, French, and English groups made contact in one form or another with many of the region's natives.

Among the various attempts to colonialize the region were expeditions led by Tristán de Luna y Arellano, who with his entourage traversed Alabama and northwest Georgia between 1559-61, attempting to establish a Spanish colony on the Alabama River (Milanich and Hudson 1993). Jean Ribaut headed a group of French Huguenots who established a colony on Port Royal Sound in 1562; they subsequently abandoned the site and moved to the mouth of St. Johns River in what is now northeastern Florida (Covington 1975). Although, John Hawkins, who in 1565 was en route home to England, saved the French from certain starvation, later that year, Pedro Menéndez ousted them and established a Spanish colony nearby (Milanich and Hudson 1993). Juan Pardo led two expeditions through what are now Georgia, South and North Carolina, and eastern Tennessee, one in 1566-1567 and the second in 1567-1568 (Hudson 1990).

In any number of documented cases, we have evidence of Europeans hunting down, capturing, and enslaving unfortunate natives as they traveled through the area. In most cases, their missions retained the character of de Soto's-they were largely exploitative and destructive. Even Catholic priests, who, under the auspices of the Spanish, were established in missions, frequently had no less devastating an effect on the native populations than had the conquistadors. Although later expeditions may have had less dramatic effects than his, the de Soto expedition nonetheless continued the process of depopulation and destabilization that had followed the earlier explorers through the region.

Another factor in the destablization of the region's political structure is recounted by Hudson (I990). Hudson contends that the European's technological advantage in various relationships of conquest and trade with the natives allowed them to intervene in established political and social relationships. In some cases this occurred because the natives had acquired from the Europeans weapons and tools that their enemies lacked and in some cases because explorers directly participated in warfare between competing chiefdoms. For instance, one of Juan Pardo's Spanish officers, having been left behind to live with the chief of Joara in what is now western North Carolina, joined an attack against the Chiscas (Hudson 1990). ${ }^{8}$ In a later expedition, de Luna helped a powerful

8. The Spanish belief that the Chiscas had gold and controlled three gold mines may have been the actual motive for the attack. 
Coosa chief in extracting tribute from a rival town which had rebelled and withheld its duty (Anderson 1996). Intervening on behalf of one chief or another was not the sole domain of the Spanish; the French engaged in intergroup warfare in Florida as well. Importantly, this gave those who were allied with the Europeans a significant advantage.

It is reasonable to conclude that European involvement in the local affairs of the native groups had a decidedly selfish motive. As an example, Hudson (1975: 16) describes the alliance formed in 1562 by French Huguenot settlers in Florida with the Timucuans, who at first "seemed to control the passageway to the Appalachian Mountains, reputedly rich in gold and silver." Consequently, the French, who joined their attack on a neighboring group, quickly severed that earlier relationship and established a new alliance with the neighboring chief who, it was discovered, actually controlled the sought-after passageway to the supposed riches of the Appalachians.

The benefits Europe received from the conquest of the Americas have been well documented. Between 1503 and 1660, during which time 32 thousand tons of silver were exported to Europe largely from Mesoamerica (Frank 1995a), world markets in silver and gold developed (Bernstein 200I). This, in turn created a new merchant and capitalist class in Europe (Weatherford 1990) where wealth had previously been based on ownership of land. Perhaps most important of all, the "age of discovery" became a global movement rather than simply a European contest for wealth and regional power.

\section{The Demise of the Mississippian Culture}

In the aftermath of the various European explorations-particularly the de Soto expedition-demographic shifts throughout the Southeast brought about significant social changes. Within two centuries of first contact, almost the entire indigenous population of the Southeast had been exterminated. Perdue (1989: 28), for example, estimates that 95 percent of the population died. As a matter of fact, Trigger and Swagerty (1996:390) maintain that the natives of the Southeast suffered the greatest decline of any region in North America. As has been noted, entire villages were depopulated by smallpox and other diseases contracted from de Soto and his men, while countless others lost many men to warfare, ambush, and murder. The Spanish also kidnapped and enslaved numerous men, women, and children with the apparent intent of transporting them to West Indies cane fields and sugar mills. These practices instituted in North America a mode of labor control similar to the one that had helped to make Spain's conquest of South and Central America so lucrative.
The published records of various explorations reveal that it was a common practice to leave behind emissaries, often to cement relations with particular chiefs. These Europeans frequently interjected themselves into local political relationships, disrupting them, and consequently contributing to the friction between various native groups and between the natives and the Europeans. Some of these disruptions were mended with time but others carried over into relations with subsequent generations of natives, explorers, and settlers and contributed to open conflict.

A second phenomenon was the beginning of 'hybridizing' the native population with the introduction of European and African blood. For instance, we know that many European soldiers escaped from their respective expeditions with the presumed intent of finding their way back to 'civilization,' stayed to live among the natives and left descendents of French, Spanish, African, and other foreign blood. For instance, Cockran $(1967: 46)$ relates that de Soto:

Left behind in the Creek country two or three deserters and strays, one of them a Negro. One of the soldiers... and the Negro settled down to Creek life and probably fathered, as did many of the army, Creek children. Thus the main contribution of this first incursion of Europeans into the Creek country was a stream of Spanish genes, tinged with Negro.

Additionally, many of the mass captures included women, some of whom were enslaved and carried to the West Indies or other locations and others who were released or escaped to return to their own people. There can be little doubt that in the wake of such incidents, numerous offspring of mixed lineage were left behind, and, because most southeastern native cultures were matrilineal (Awiakta 1993; Green 1992; see also Perdue 1999), offspring, regardless of paternity, would have automatically been integrated into the mother's clan. At the same time Europeans began the hybridization of the indigenous population (Cockran 1967), they also began the 'whitening' of the native population and the beginning of a racial phenomenon that in time would greatly transform internal class relations.

Chiefdoms that had managed to survive contact with Europeans had been permanently altered - their cultures had been modified to accommodate new political and power relations and to incorporate foreign technology, goods, and customs. Most chiefdoms had been weakened and replaced by a "lower level of sociopolitical complexity" (Hally 1996) and were succeeded by more politically decentralized tribes (Smith 1978; Smith 1992). At the same time their economic organization had shifted from a sustainable and diversified economy that incorporated horticulture, hunting and foraging, and trade in various products including prestige goods to an increased dependence on hunting (Cochran 
1967), particularly hunting necessary to secure the fur they produced for export to Europe (Dunaway 1994). Although the effect would not show itself immediately, the introduction of horses was part of this transformation (Dunaway 1997); their adoption into the native culture led to increased mobility that, in turn, contributed to an increased dependence on hunting. The native populations thereafter were more susceptible to seasonal and climatic variations and became more migratory, and consequently often finding themselves in conflict with neighboring groups with whom they competed for territory, increasingly scarce game, and trade routes (Trigger and Swaggerty 1996).

Contact with Europeans undermined the power, privilege, and prestige that had been enjoyed by powerful chiefs and headmen and which had contributed to the stability of what otherwise was a relatively fragile population. For instance, Hudson (1990) and others conclude that the destruction and theft of stores of corn needed by the village leaders to sustain the local people over the winter or though periods of low crop yields disrupted the native economy (see also Dunaway 1994), almost certainly leading to protracted periods of hunger and undernourishment. ${ }^{9}$ That in turn would have directly contributed to the changes in birth and mortality rates, both of which helped speed demographic changes and relocations, further diminishing the population's vitality, accelerating system decline, and undermining the legitimacy of elite leaders. Additionally, Trigger and Swagerty (1996) assert that, because of their having been overworked under forced conditions and enslavement, along with the increased death rate, the population declined significantly. Furthermore, because family relations were disrupted, the indigenous birth rate fell drastically, a phenomenon that had a serious impact on the native population's ability to regain self-sufficiency and to defend itself. In sum, disease and malnutrition had rendered the population too weak to seek new sources of food, care for its young, or to physically and socially reproduce itself (McNeil I989).

The European expedition leaders who sought to establish dominance over the native populations also undermined in a number of ways the elite structures of accumulation, which had contributed to the stability of the economic arrangements, legitimacy of the system, and status of chiefs. First, they introduced European goods, particularly weapons and armor, into the indigenous system of trade. Second, European explorers, who presented themselves as supreme chiefs, kings, and emissaries of God, frequently demanded allegiance

9. Hudson (1976: 74) documents numerous cases of de Soto's forces seizing stored corn from villages and administrative centers throughout the region. and tribute from local chiefs, disrupting the indigenous political alliances. Both de Soto (Milanich and Hudson 1993) and Juan Pardo (Hudson 1990) had arbitrarily 'designated' new high chiefs along the route as a matter of convenience and in order to secure food and other provisions for themselves. Thus, a realignment of intergroup loyalties was effected and almost certainly had far-reaching effects in terms of information and power networks. These transformations were important because the nature of the relations between the various groups in their prior state had been indicative of early pre-state formations that might otherwise have been expected to develop (Pauketat 1994; Trigger and Swagerty 1996). They also suggest that the political structures that had existed in indigenous southeastern societies before European contact influenced the nature of that contact.

Hudson (1976: 206) argues that, although trade continued between native groups and with European explorers, many of the material symbols and artifacts associated with the earlier powerful chiefdoms suddenly disappeared soon after contact. This appears to have been caused by the collapse of the complex chiefdoms and the entire Mississippian system. This is evidenced by the appearance, where there had earlier been powerful chiefdoms, of a number of loosely confederated groups (Scarry 1996b: 226) that appears to have resulted in the relocation of entire culture groups from one area to another.9 This is important because, although village groups often changed locations in the Mississippian era, they most often involved movement across short distances. Furthermore, following contact with Europeans, this pattern became much more common, seemingly because of the breakdown of political structures (Wolf i982; Hudson 1990) that had encouraged trade and communication across long distances.

The social formations that emerged from the widely dispersed Mississippian groups formed what came to be identified as the southeastern Indian 'tribes' with whom the later settlers came into contact in the seventeenth and eighteenth centuries. The Cherokee, whose ancestors had lived east of the Appalachian Mountains and deep in the mountains on the Nolichucky and French Broad rivers, relocated before 1700 farther west and south. East of the Appalachians, what had before been several chiefdoms reformed into two distinct bands, the Upper and Lower Cherokee. Hoig (1998: I0) contends that the 'more rebellious' groups that lived on the Nolichucky and French Broad formed the Overhill Cherokee as a separate group and moved into the Little Tennessee River valley, which had earlier been occupied by Muskogean people (Hudson 1976). The Muskogeans, in turn, had relocated farther south, into Georgia and Alabama. The great Muskogean paramount chiefdom Coosa, which had been located at the headwaters of the Coosa River in north Georgia, upon disintegration, had reappeared some distance further to the southwest in central Alabama. 
There, they joined with other groups to form what began to be identified by Europeans as the Creek Nation. ${ }^{10}$ Others retreated further south into what is now Florida. ${ }^{11}$

The eighteenth-century native American chronicler James Adair observed that except for their languages, these various southern groups had far more cultural similarities than differences (Hudson 1976). This could be accounted for by their having had common roots in the Mississippian system. Nonetheless, Bruce Smith (1978) asserts that in a number of ways they were a noticeably different people than their ancestors with whom Europeans first had contact: (I) They were more loosely connected to other groups throughout the region and more competitive and warlike; (2) many had reverted from organized horticulture to a more nomadic existence and increased dependence on hunting and gathering for their subsistence; and (3) most importantly, their populations had thinned dramatically and both their natural and military defenses were weakened.

\section{DISCUSSION AND CONCLUSIONS}

Although the conquerors had not drawn the southeastern region into a clearly established division of labor in the production and export of bulk goods, as Hopkins and Wallerstein (1987) have suggested is necessary for incorporation, beginning with early contact Europeans had 'harvested' slaves from within the Mississippian system and had exchanged them into the circuits of trade that made up the Atlantic colonial complex. They traded enslaved native Americans to West Indian and South American planters in exchange for gold, silver, and sugar, which in turn were traded, possibly in "southern India for indigo-died cloths that were in demand in Senegal. These cloths might have been sold in Senegal-not for slaves, but for gum and for Senegalese cloths that were in demand farther down the coast in Dahomey. In exchange, Europeans would have gained ownership of enslaved Dahomeians, which would have been sold,

10. Hudson (1975:3) identifies the southeastern tribes in the historic period by their language groups, as follows: Algonkian (e.g. Powhatan and Shawnee), Iroquoian (e.g. Cherokee and Tuscarora), Siouan (e.g. Tutelo, Biloxi, Catawba), and Muskogean (e.g. Choctaw, Chickasaw, Alabama, and Creek). Although other languages groups existed in the South, the above included most of the region's population and can be traced to the pre-Columbian people, most of whom had been part of the Mississippian system.

11. A part of the Creek Confederacy forced out of Georgia formed the Seminole move to Florida, one of the last tribes to arrive on the Florida peninsula (J. Wright I986). in turn, in the New World, and variants of the same cycle could be played out again" (Curtin 1990: 142). In short, this was the emergence of the Atlantic circuit of trade that became increasingly important in the development of Europe and parts of America, the underdevelopment of Africa, and the peripheralization of the West Indies and the American South. Maize, which was indigenous to the area, entered that circuit of trade around 1500 when missionaries, merchants, and slave traders transported its seeds to Africa (McCann 200I). This set into motion in the Old World changes in the production of food crops that was perhaps one of the most significant ecological consequences of European contact with the western hemisphere (Crosby 1972; Hobsbawm 1992; Lang 1975).

It would be many decades before the US South would be fully incorporated into the world-economy, in large part because its early contact with the worldsystem-which I suggest here was a form of incorporation-made it a part of the Atlantic economic complex that emerged from the contest among European powers for territory and wealth. It was also important that the struggle by western European nations for world hegemony in the southeastern part of North America contributed to the weakening of the Dutch and the rise of Spain, England, and Portugal (Parry 196I). The incorporation by various European powers of the different parts of the Americas also contributed to the development of Europe's economy, in terms of both supply and demand; in particular it supplied, as has been shown, enslaved workers to the West Indian and Brazilian sugar economies that were important in the European circuits of trade. And as is evidenced by the transfer over long distances of artifacts from early European contact, it created in the native populations a demand for European goods that entered their own prestige goods trade networks and inextricably altered political and social relations. And, more importantly perhaps, it resulted in significant demographic changes that weakened resistance, decentralized political control, and increased intertribal conflict.

The primary goal of the current study has been to consider the concept of incorporation within the context of historical evidence left by European contact with the North American Southeast. The reciprocal role incorporation played between the indigenous populations of the North American Southeast and the capitalist world-system reveals a great deal more about the effect of contact on populations external to the system than had previously been thought. Many scholars have considered incorporation of the area to have effectively begun with English settlement in 1608 (see e.g. Dunaway 1996). This, I argue, overlooks the vast amount of historical data about pre-settlement contacts and their effect on both the indigenous populations and the European economies. As the current study illustrates, the indigenous populations were dramatically changed by the contact so that they ceased to be external to the world-system, 
a perspective that has been strengthened by clarifying the effect contact had on the relationships of the various European actors with the native peoples and the natives' relationships with each other.

Given the frequency and extent of conquest and plunder and the transformation of internal social, political, and economic structures, the evidence presented here suggests that by 1600 Europeans had already incorporated the region into the world-economy and the region had for some decades ceased to be 'external' to the European capitalist world-economy. Because the transformation that took place in the sixteenth century did not involve a complete articulation of capitalism, the form of incorporation that is most applicable to the region falls along the 'contact' and the 'marginal' end of Chase-Dunn and Hall's (1997) continuum of incorporation. In the process of contact and the beginning of incorporation, the internal structures of accumulation in the Mississippian system had been transformed and the mode of accumulation, which had earlier been characterized by many of the features of a tributary system, had receded and political structures and modes of accumulation had been permanently transformed. Importantly, if contact with Europeans had ceased at any point after 1530 the Mississippian system would almost certainly have been unable to reestablish itself and certainly not in its earlier form. ${ }^{12}$ And, at the same time, the social, economic, and political relations among European economic actors were sufficiently changed by the incorporation of the region that, had contact ended prior to 1608 , the capitalist world-system almost certainly would not have returned to its pre-contact condition; much like the North American Mississippian societies, it had been permanently transformed by the experience.

In conclusion, this research draws together evidence that the early European contact in the southeastern portion of North American not only contributed to the establishment of trade relations with other parts of the emerging worldsystem, but also led to the subsequent planting of European settlements on the North American continent. Second, it emphasizes the fact that, at a time when the institutions of slavery and serfdom were subsiding in their homelands, Western Europeans were extending plantation economies into the New World

12. Hall (I989: 2I) clarifies the importance of this point by explaining that "the stronger previous incorporation had been, the larger the obstacles to reversal and the more difficult it would be for the social structure to return to the status quo ante. Arrighi (I979: I6I-I62) likewise contends that "should for any reason political domination cease and/or economic relations with the capitalist world-economy be severed, there would be a tendency toward the re-establishment of those patterns." and, simultaneously, infusing Europe with new sources of wealth. Third, it suggests that experience gained by Europeans in their early incorporation of the southeastern portion of North America contributed to the struggle between Spain, England, France, Portugal, and other European nations in their quest for economic dominance and opened the way for the rise of the first global empires in world history, along with the incumbent conflicts that followed. Fourth, I conclude that from this milieu, the early agents of capitalism expanded the emerging network of world-wide commercial trade and European capitalist enterprise, and, in the process, established a model of imperialism that would guide subsequent conquests and lay the foundation for what would become a global movement.

\section{REFERENCES}

Abu-Lughod, Janet L. 1989. Before European Hegemony: The World System A.D. 12501350. Oxford: Oxford University Press.

Anderson, David G. 1994. The Savannah River Chiefdoms: Political Change in the Late Prebistoric Southeast. Tuscaloosa, University of Alabama Press.

. I996. "Fluctuations between Simple and Complex Chiefdoms: Cycling in the Late Prehistoric Southeast." pp. 233-252 in Political Structure and Change in the Prehistoric Southeastern United States, edited by John F. Scarry. Gainesville: University Press of Florida.

Anderson, William L., ed. 1991. Cherokee Removal Before and After. Athens, GA: University of Georgia Press.

Arrighi, Giovanni. 1979. "Peripheralization of Southern Africa, I: Changes in Production Processes." Review 3: I6I-92.

Awiakta, Marilou. 1993. Selu: Seeking the Corn-Mother's Wisdom. Golden, CO: Fulcrum Publishing.

Baran, Paul A. 1957. The Political Economy of Growth. New York: Monthly Review Press.

Barker, Alex W. 1992. "Powhatan's Pursestrings: On the Meaning of Surplus in a Seventeenth Century Algonkian Chiefdom." pp. 6I-80 in Lords of the Southeast: Social Inequality and the Native Elites of Southeastern North America, edited by A. W. Barker and T. R. Pauketat. Washington, DC: Smithsonian Institution Press.

Beers, George Louis. 1908. The Origins of the British Colonial System: 1578-1660. New York: Macmillan.

Bernstein, Peter L. 200I. The Power of Gold: The History of an Obsession. New York: John Wiley \& Sons

Bourne, Edward Gaylord, ed. 1922. Narratives of the Career of Hernando de Soto in the Conquest of Florida, 2 vols. New York, NY: Allerton Book.

Bradby, Barbara. 1980. "The Destruction of Natural Economy." Pp. 93-I27 in The Articulation of Modes of Production, edited by H. Wolpe. London: Routledge and Kegan Paul. 
Brown, Douglas S. 1966. The Catawba Indians: The People of the River. Columbia: University of South Carolina Press.

Carlson, Jon D. 200I. "Broadening and Deepening: Systemic Expansion, Incorporation and the Zone of Ignorance." Journal of World-Systems Research 7(2):225-263. http://jwsr.ucr.edu

2002. "The 'Otter-Man' Empires: The Pacific Fur Trade, Incorporation and the Zone of Ignorance," Journal of World-Systems Research 8(3):390-442. $\underline{\text { http: //jwsr.ucr.edu }}$

Carneiro, Robert L. 198I. "The Chiefdom: Precursor of the State." Pp. 37-75 in The Transition to Statehood in the New World, edited by G. D. Jones and R. R. Krautz. Cambridge: Cambridge University Press.

Chase-Dunn, Christopher. 1998. Global Formation: Structures of the World-Economy. Second edition. Lanham, MDः Rowman and Littlefield. Originally published I989.

Chase-Dunn, Christopher, and Thomas D. Hall. 1997. Rise and Demise: Comparing World-Systems. Boulder, CO: Westview Press.

. 1998. "World-Systems in North America: Networks, Rise and Fall and Pulsations of Trade in Stateless Systems," American Indian Culture and Research Journal 22(I): 23-72.

Cockran, David H. 1967. The Creek Frontier: 1540-1783. Norman: University of Oklahoma Press.

Cotterill, Robert S. 1954. The Southern Indians: The Story of the Civilized Tribes before Removal. Norman: University of Oklahoma Press.

Covington, James W. I975. "Relations Between the Eastern Timucuan Indians and the French and Spanish: I564-1567." PP. II-27 in Four Centuries of Southern Indians, edited by C. M. Hudson. Athens: University of Georgia Press.

Crosby, Alfred W. 1972. The Columbian Exchange: Biological and Cultural Consequences of 1492. Westport, CT: Greenwood Press.

1986. Ecological Imperialism: The Biological Expansion of Europe, 900-1900. New York: Cambridge University Press

Croxton, Derek. I990. "The Cabot Dilemma." Essays in History 33. Retrieved June I3, 1999 (http://etext.lib.virginia.edu/journals/EH/EH33).

Curren, Caleb. 1984. The Protohistoric Period in Central Alabama. Camden: Alabama Tombigbee Regional Commission.

Curren, Caleb, Keith J. Little, and George E. Lankford. 1982. "Archaeological Research Concerning I6th Century Spanish and Indians in Alabama." An unpublished report to the Alabama-Tombigbee Regional Commission, cited in Curren I984.

Curtin, Phillip D. 1990. The Rise and Fall of the Plantation Complex. New York: Cambridge University Press.

De Pratter, Chester. 1983. "Late Prehistoric and Early Historic Chiefdoms in the Southeastern United States." Ph.D. Dissertation, University of Georgia, Athens.

Dunaway, Wilma A. I994. "The Southern Fur Trade and the Incorporation of Southern Appalachia into the World-Economy, I690-I763." Review 17:215-42.
Contact, Incorporation, and the North American Southeast

. 1996. "Incorporation as an Interactive Process: Cherokee Resistance to Expansion of the Capitalist World-System, I560-I763." Sociological Inquiry $66: 455-467$.

. 1997. "Rethinking Cherokee Acculturation: Agrarian Capitalism and

Women's Resistance to the Cult of Domesticity, I800-1838." American Indian Culture and Research Journal 21:155.

Earle, Timothy K. 1987. "Chiefdoms in Archaeological and Ethnohistorical Perspective." Annual Review of Anthropology 16:279-308.

Frank, Andre Gunder, 1973. "The Development of Underdevelopment." PP. 96-104 in The Political Economy of Development and Underdevelopment, edited by Charles K. Wilber. New York: Random House.

.I978a. Dependent Accumulation and Underdevelopment. London: Macmillan Press.

. I978b. "Development and Underdevelopment in the New World." Theory and Society $2(4) \div 43 I-465$.

. 1995a. "Asian-Based World Economy I400-1800: A Horizontally

Integrative Macrohistory.” H-NET List for World History (h-world@msu.edu). . I995b. "The Modern World System Revisited: Rereading Braudel and

Wallerstein." PP. I63-I94 in Civilizations and World Systems: Studying WorldHistorical Change, edited by S. K. Sanderson. Walnut Creek, CA: AltaMira Press.

Frank, Andre Gunder, and Barry K. Gills. 1993. The World System: Five Hundred Years or Five Thousand? New York: Routledge.

Galloway, Patricia. 1995. Choctaw Genesis: 1500-1700. Lincoln: University of Nebraska Press.

Green, Rayna. 1992. Women in American Indian Society. New York: Chelsea House Publishers.

Hall, Robert L. I99I. "Cahokia Identity and Interaction Models of Cahokia Mississipian." PP. 3-34 in Cahokia and the Hinterlands, edited by T. E. Emerson and R. B. Lewis. Urbana: University of Illinois.

Hall, Thomas D. 1986. "Incorporation in the World-System: Toward A Critique." American Sociological Review 5I(3): 390-402. .1987. "Native Americans and Incorporation: Patterns and Problems." American Indian Culture and Research Journal II(2):I-30.

.1989. Social Change in the Southwest, 1350-1880. Lawrence: University Press of Kansas.

. 1996. World-Systems and Evolution: An Appraisal. Journal of World-Systems Research 2(4). http://jwsr.ucr.edu

Hally, David J. I993. "The Territorial Size of Mississippian Chiefdoms. PP. I43-168 in Archaeology of Eastern North America, edited by J. Stoltman. Jackson: Mississippi Department of Archives and History. 
. 1996. "Platform-Mound Construction and the Instability of Mississippian Chiefdoms." PP. 92-I27 in Political Structure and Change in the Prebistoric Southeastern United States, edited by J. F. Scarry. Gainesville: University Press of Florida.

Hally, David J., Marvin T. Smith, and James B. Langford, Jr. 1990. “The Archaeological Reality of de Soto's Coosa. PP. I2I-I38 in Columbian Consequences II: Archaeological and Historical Perspectives on the Spanish Borderlands East, edited by D. H. Thomas. Washington, DC: Smithsonian Institution Press.

Hobsbawm, Eric. 1992. "Goodbye Columbus." London Review of Books I4(I3):14-15.

Hoig, Stanley W. 1998. The Cherokee and their Chiefs: In the Wake of Empire. Fayetteville: University of Arkansas Press.

Hollis, Shirley A. 2000. "Between God and Markets: Class, Race, and State in the Underdevelopment of the American South." Ph.D. Dissertation, University of Tennessee, Knoxville.

Hopkins, Terence K., and Immanuel Wallerstein. I982. "Structural Transformations of the World-Economy." PP. I2I-I42 in World-Systems Analysis: Theory and Methodology, edited by T. K. Hopkins and I. Wallerstein. Beverly Hills: Sage.

. 1987. "Capitalism and the Incorporation of New Zones into the WorldEconomy." Review Io(5/6): 763-779.

Hudson, Charles M. 1975. Four Centuries of Southern Indians. Athens: University of Georgia Press.

. 1976. The Southeastern Indians. Knoxville: University of Tennessee Press.

. 1990. The Juan Pardo Expeditions: Exploration of the Carolinas and Tennessee, 1566-1568. Washington, DC: Smithsonian Institution Press.

Jennings, Francis. 1975. The Invasion of America: Indians, Colonialism, and the Cant of Conquest. Chapel Hill: University of North Carolina Press.

Jeske, Robert J. 1999. "World-Systems Theory, Core-Periphery Interactions, and Elite Economic Exchange in Mississippian Societies." PP. 203-22I in WorldSystems Theory in Practice: Leadership, Production, and Exchange, edited by P. N. Kardulias. Lanham, MD: Rowman \& Littlefield.

Johnson, Jay K. I994. "Prehistoric Exchange in the Southeast." PP. 99-I26 in Prehistoric Exchange Systems in North America, edited by T. G. Baugh and J. E. Ericson. New York: Plenium Press.

Keel, Bennie C., John E. Cornelison, Jr., and David M. Brewer. 1996. "Regionwide Archeological Survey Plan, Southeast Field Area, National Park Service." Tallahassee, FL: Southeast Archeological Center, National Park Service.

Kelley, John E. 199I. "Cahokia and Its Role as a Gateway Center in Interregional Exchange." pp. 6I-82 in Cahokia and the Hinterland: Middle Mississippian Cultures of the Midwest, edited by T. E. Emerson and R. B. Lewis. Urbana: University of Illinois Press.

Kelly, Lucretia S. 1997. Patterns of Faunal Exploitation of Cahokia." pp. 69-88 in Cahokia: Domination and Ideology in the Mississippian World, edited by T.R. Pauketat and T. E. Emerson. Lincoln: University of Nebraska Press.
Knight, Vernon J., Jr. 1990. "Social Organization and the Evolution of Hierarchy in Southeastern Chiefdoms." Journal of Anthropological Research 46(I ):I-23

Kowalewski, Stephen A. 1996. "Clout, Corn, Copper, Core-Periphery, Culture Area." PP. 27-38 in Pre-Columbian World-Systems, edited by P. Peregrine and G. M. Feinman. Madison, WI: Prehistory Press.

LaLone, Darrell. 1999. “ Does World-Systems Theory Work?ः An Ethnographer's Perspective." Pp 297-307 in World-Systems Theory in Practice: Leadership, Production, and Exchange, edited by P. Nick Kardulias. Lanham, MD: Rowman $\&$ Littlefield.

Lang, James. 1975. Conquests and Commerce: Spain and England in the Americas. New York: Academic Press.

Larson, Lewis H. 1980. Aboriginal Subsistence Technology on the Southeastern Coastal Plain During the Late Prehistoric Period. Gainesville: University Presses of Florida.

Lewis, R. Barry. 2000. "The Early Mississippi Period in the Confluence Region and Its Northern Relationships." Pp. 274-294 in Cahokia and the Hinterlands: Middle Mississippian Cultures of the Midwest, edited by T. E. Emerson and R. B. Lewis. Urbana: University of Illinois Press.

Martin, William G. I994. "The World-Systems Perspective in Perspective: Assessing the Attempt to Move beyond Nineteenth-Century Eurocentric Conceptions." Review I7(2):145-I85

Marx, Karl, and Frederick Engels. 1962. "The Manifesto of the Communist Party." In Selected Works, vol. I., edited by Vladimir V. Adoratsky. Reprint of I935 edition. Moscow, Leningrad: Foreign Languages Publishing House.

McCann, James. 200I. "Maize and Grace: History, Corn, and Africa's New Landscapes, 1500-1999." Comparative Studies in Society and History 43:246-272.

McGovern, Thomas. 1980. "The Vinland Adventure: A North Atlantic Perspective." North American Archaeologist 2: 285-308.

McNeill, William. 1989. Plagues and Peoples. Originally published in 1976. New York: Anchor Books.

Mehrer, M., and J. M. Collins. 1995. "Household Archaeology at Cahokia and its Hinterlands." Pp. 32-57 in Mississippian Communities and Housebolds, edited by J. D. Rogers and B. D. Smith. Tuscaloosa: University of Alabama Press.

Milanich, Jerald T., and Charles Hudson. 1993. Hernando de Soto and the Indians of Florida. Gainesville: University Presses of Florida.

Milner, G. R., E. Anderson, and V. G. Smith. I991. "Warfare in Late Prehistoric West-Central Illinois." American Antiquity 56: 58I-603.

Mooney, James. 1982. Myths of the Cherokee and Sacred Formulas of the Cherokee, I9th and 7th Annual Reports, Bureau of Ethnology. Reprint, Nashville, TN: Charles and Randy Elder.

Muller, Jon. 1997. Mississippian Political Economy. New York: Plenum Press.

Nash, Gerald D., ed. 1964. Issues in American Economic History. Boston: Heath.

Nash, Gary B. 1992. Red, White, and Black: The Peoples of Early North America. Third edition. Englewood Cliffs, NJ: Prentice Hall. 
Nassaney, Michael S. 1989. "An Epistemological Inquiry into Some Archaeological and Historical Interpretations of 17 th Century Native American-European Relations." pp. 76-93 in Archaeological Approaches to Cultural Identity, edited by S. Shennan. London: Unwin Hyman.

O’Brien, Patricia J 1992. "The 'World-System' of Cahokia within the Middle Mississippian Tradition." Review I5(3): 389-4I7.

Osgood, Herbert L. 1904. The American Colonies in the Seventeenth Century. New York: Macmillan.

Parry, John H. 196I. The Establishment of the European Hegemony: 1415-1716, Trade and Exploration in the Age of the Renaissance. New York: Harper Torchbooks.

Pauketat, Timothy R. 1994. The Ascent of Chiefs: Cahokia and Mississippian Politics in Native North America. Tuscaloosa: University of Alabama Press.

Pauketat, Timothy R. and Thomas E. Emerson, eds. 1997. Cahokia: Domination and Ideology in the Mississippian World. Lincoln: University of Nebraska Press.

Peebles, C. S. 1983. "Moundville: Late Prehistoric Sociopolitical Organization in the Southeastern United States." PP. 183-198 in The Development of Political Organization in Native North America: 1979 Proceedings of the American Ethnological Society, edited by E. Tooker. Washington, CD: American Ethnological Society.

Perdue, Theda. 1989. The Cherokee. In Indians of North America Series, Sam Tanenhaus, ed. New York, NY: Chelsea House.

. 1999. Cherokee Women: Gender and Culture Change, 1700-1835. Lincoln,

NE: University of Nebraska Press.

Peregrine, Peter. 1992. Mississippian Evolution: A World-System Perspective. Madison, WI: Prehistory Press.

. I996a. "Introduction: World-Systems Theory and Archaeology." PP. I-Io

in Pre-Columbian World-Systems, edited by P. N. Peregrine and G. M. Feinman. Madison, WI: Prehistory Press.

. 1996b. "Legitimation Crises in Premodern Worlds." Journal of World-

Systems Research 2(6): I-26. http://jwsr.ucr.edu

. I999. "Corporate and Network Political Strategies in the Evolution of

Mississippian Societies." Paper presented at the annual meeting of the American Sociological Association, Chicago, IL, August I999.

Porter, J. W. 1974. "Agricultural Productivity, Population Pressure and Archaeological Site Location in the Georgia Piedmont." Unpublished M.A. thesis, Department of Anthropology, Pennsylvania State University.

Sauer, Carl O. 1966. The Early Spanish Main. Berkeley: University of California Press.

Scarry, John F. I996a. "The Nature of Mississippian Societies." PP. I2-24 in Political Structure and Change in the Prehistoric Southeastern United States, edited by J. F. Scarry. Gainesville: University Press of Florida.

. I996b. "Stability and Change in the Apalachee Chiefdom." pp. I92-227 in Political Structure and Change in the Prehistoric Southeastern United States, edited by J. F. Scarry. Gainesville: University Press of Florida.
Contact, Incorporation, and the North American Southeast

Schneider, Jane. I99I. "Was There a Pre-Capitalist World-System?” pP. 45-64 in Core/Periphery Relations in Precapitalist Worlds, edited by Christopher ChaseDunn and Thomas D. Hall. Boulder, CO: Westview.

Service, Elman Rogers. I97I. Primitive Social Organization: An Evolutionary Perspective. New York: Random House

Shannon, Thomas R. 1996. An Introduction to the World-System Perspective. Boulder, CO: Westview Press.

Smith, Adam. 1937. An Inquiry into the Nature and Causes of the Wealth of Nations. New York, NY: Random House. Originally published 1776.

Smith, Bruce D. 1978. Mississippian Settlement Patterns. New York, NY: Academic Press.

. I990. "Introduction." Pp. I-8 in The Mississippian Emergence: The Evolution of Ranked Agricultural Societies in the Eastern United States, edited by B. D. Smith. Washington, DC: Smithsonian Institution Press.

Smith, Marvin T. 1987. "Archaeology of Aboriginal Culture Change in the Interior Southeast: Depopulation During the Early Historic Period," cited in Jay K. Johnson, 1994, p. Ioo and in Trigger and Swagerty, I996, p. 364.

. 1992. Archaeology of Aboriginal Culture Change in the Interior Southeast: Depopulation During the Early Historic Period. Reprint of 1987 edition. Gainesville, FL: University of Florida Press.

. 2000. Coosa: The Rise and Fall of a Southeastern Mississippian Chiefdom. Gainsville: University of Florida.

Smith, Marvin T., and David J. Hally. 1992. "Chiefly Behavior: Evidence from Sixteenth Century Spanish Accounts." pp. 99-1 Io in Lords of the Southeast: Social Inequality and the Native Elites of Southeastern North America, edited by A. W. Barker and T. R. Pauketat. Washington, DC: Smithsonian Institution Press.

So, Alvin Y. 1990. Social Change and Development: Modernization, Dependenc, and World-System Theories. Newbury Park: Sage.

Swanton, John. 1946. The Indians of the Southeastern United States. Washington, DC: Government Printing Office.

Trigger, Bruce G., and William R. Swagerty. I996. "Entertaining Strangers: North America in the Sixteenth Century." Pp. 325-398 in The Cambridge History of the Native Peoples of the Americas. Vol. I , North America, pt. I, edited by B. G. Trigger and W. E. Washburn. Cambridge: Cambridge University Press.

Wallerstein, Immanuel. 1974. The Modern World-System I: Capitalist Agriculture and the Origins of the European World-Economy in the Sixteenth Century. San Diego, CA: Academic Press.

. 1988. "The Ideological Tensions of Capitalism: Universalism versus Racism and Sexism." pp. 29-36 in Racism, Sexism, and the World-System, ed. J. Smith, J. Collins, T. K. Hopkins, and A. Muhammad. New York: Greenwood Press, I988. Weatherford, Jack. 1990. Indian Givers. New York: Ballantine Books.

Welch, Paul D. 1986. "Models of Chiefdom Economy: Prehistoric Moundville as a Case Study.” Ph.D. Dissertation, University of Michigan, University Microfilms, Ann Arbor. 
Wolf, Eric R. 1982. Europe and the People without History. Berkeley: University of California Press.

Wright, Gavin. 1986. Old South, New South: Revolutions in the Southern Economy Since the Civil War. New York: Basic Books

Zinn, Howard. I980. A People's History of the United States. New York: Harper and Row. 